\title{
Diagnosis and Management of Inherited Platelet Disorders
}

\author{
Carl Maximilian Kirchmaier Daniele Pillitteri \\ Deutsche Klinik für Diagnostik, Sektion Innere Medizin I, Arbeitsgruppe: «Thrombose, Hämostase und vaskuläre Medizin», \\ Wiesbaden, Germany
}

\section{Keywords}

Inherited platelet function disorders .

Diagnosis - Therapy

\section{Summary}

In clinical daily practice the definition of a bleeding tendency is rather subjective. Clinical manifestations usually include hematoma, epistaxis, menorrhagia, and severe bleeding episodes after surgery or injuries. The most common causes are disorders of primary hemostasis that occur sometimes due to platelet function disorders. Inherited thrombocytopathies are much less frequent in comparison to acquired platelet function disorders. However, congenital disorders can lead to severe bleeding tendency and are often not diagnosed. They are induced by different platelet defects based on disorders of platelet adhesion, receptors, secretion, and signal transduction. In some cases, they are associated with thrombocytopenias, giant platelets, and various comorbidities. This article gives an overview of the different defects, their diagnosis, and treatment options.

\section{Introduction}

In clinical daily routine it is quite difficult to detect pathological bleeding tendencies. Physicians are often confronted with patients suffering from apparently excessive or frequent unprovoked bleeding, most commonly epistaxis or menorrhagia,

\section{Schlüsselwörter}

Angeborene Thrombozytenfunktionsstörungen . Diagnostik - Therapie

\section{Zusammenfassung}

Im klinischen Alltag ist die Definition einer Blutungsneigung meistens sehr subjektiv. Es werden verstärkte Hämatomneigung, Nasenbluten, Menorrhagien und eine verstärkte Blutung nach Verletzungen oder Operationen angegeben. Als häufigste Ursachen finden sich Störungen der primären Hämostase, die zum Teil auf eine Thrombozytenfunktionsstörung zurückzuführen sind. Angeborene Thrombozytopathien sind sehr viel seltener als erworbene Thromboyztenfunktionsstörungen. Hereditäre Störungen führen jedoch teilweise zu einer schweren Blutungsneigung und werden oft nicht erkannt. Ihnen liegen unterschiedliche Defekte der Thrombozyten zugrunde, die auf Störungen der Adhäsion, der Thromboyztenrezeptoren, Freisetzungsstörungen der Plättcheninhaltsstoffe und Blockaden der Signaltransduktionswege zurückzuführen sind. In einigen Fällen sind sie mit einer moderaten Thrombozytopenie, Riesenplättchen und verschiedenen Komorbiditäten vergesellschaftet. In diesem Artikel wird eine Übersicht über die unterschiedlichen Defekte, ihre Diagnosen und die Behandlungsmöglichkeiten gegeben.

or at parturition. The most common cause of bleeding is the disorder of primary hemostasis, in particular defects of platelet function (thrombocytopathy). Even though inherited thrombocytopathies are much less frequent in clinical practice than acquired thrombocytopathies [1], they deserve special attention because inherited platelet disorders are usually more

\section{KARGER}

Fax +497614520714

Information@Karger.de

www.karger.com (c) 2010 S. Karger GmbH, Freiburg

Accessible online at:

www.karger.com/tmh 
Table 1. Classification of inherited disorders of platelet function

\begin{tabular}{|c|c|c|}
\hline Disorder & Type & Abnormality \\
\hline $\begin{array}{l}\text { Disorders of aggregation } \\
\quad \text { (defects in platelet-platelet } \\
\text { interaction) }\end{array}$ & Glanzmann thrombasthenia & deficiency or defect in GP IIb-IIIa \\
\hline $\begin{array}{l}\text { Disorders of adhesion } \\
\quad \text { (defects in platelet-vessel } \\
\text { wall interaction) }\end{array}$ & $\begin{array}{l}\text { Bernard-Soulier syndrome } \\
\text { platelet-type von Willebrand disease }\end{array}$ & deficiency or defect in GP Ib-IX-V \\
\hline $\begin{array}{l}\text { Disorders of platelet secretion } \\
\text { (primary secretion defects) } \\
\text { and signal transduction }\end{array}$ & $\begin{array}{l}\text { defects in platelet-agonist interactions } \\
\text { abnormalities in arachidonic acid } \\
\text { path-ways or thromboxane } \mathrm{A}_{2} \text { synthesis } \\
\text { defects in G-protein activation } \\
\text { defects in phosphatidylinositol meta-bolism } \\
\text { defects in protein phosphorylation } \\
\text { defects in calcium mobilization }\end{array}$ & $\begin{array}{l}\text { deficiencies of receptors for ADP, } \\
\text { collagen, epinephrine or thromboxane } \mathrm{A}_{2} \\
\text { impaired liberation of arachidonic acid, } \\
\text { cyclooxygenase deficiency or } \\
\text { thromboxane synthase deficiency } \\
\text { Goq deficiency } \\
\text { phospholipase C- } \beta 2 \text { deficiency } \\
\text { PKC deficiency (Pleckstrin) }\end{array}$ \\
\hline $\begin{array}{l}\text { Disorders of platelet secretion } \\
\text { and abnormalities of } \\
\text { granules }\end{array}$ & storage pool diseases $(\delta, \alpha, \alpha \delta)$ & $\delta$-granules, $\alpha$-granules or both \\
\hline $\begin{array}{l}\text { Disorders of procoagulant } \\
\text { function }\end{array}$ & Scott syndrome & membrane phospholipid defects \\
\hline $\begin{array}{l}\text { Defects in structural or } \\
\text { cytoskeletal components }\end{array}$ & $\begin{array}{l}\text { MYH9-related disorders } \\
\text { Wiskott-Aldrich syndrome }\end{array}$ & \\
\hline
\end{tabular}

serious regarding the bleeding tendency. Inherited thrombocytopathies are related to different platelet defects, including defects of platelet adhesion, receptors, secretion, signaling pathways, and enzymes [2-7]. In addition, some platelet function disorders may be associated with thrombocytopenia, giant platelets, and/or typical comorbidities. In the first part of this article, a survey is given on the most common inherited thrombocytopathies. A simplified classification is shown in table 1. Afterwards, we discuss the diagnosis and management of those platelet disorders.

\section{Specific Disorders of Platelet Function}

\section{Defects of Platelet Receptors}

\section{Glanzmann Thrombasthenia}

Glanzmann thrombasthenia (GT) is a rare, autosomal-recessively inherited bleeding syndrome caused by quantitative and/or qualitative abnormalities in the platelet fibrinogen receptor, the $\alpha_{\mathrm{IIb}} \beta_{3}$ integrin (glycoprotein (GP) IIb/IIIa, CD41/ CD61) which mediates the incorporation of platelets into an aggregate or thrombus at sites of vessel injury [8, 9]. Laboratory parameters in severe GT show no platelet aggregation in response to all physiologic agonists and reduced or absent clot retraction. When these two findings are associated with normal platelet count and size, the diagnosis of GT is distinct. However, the diagnosis of GT should be confirmed by flow cytometry. In addition to quantitative determination of $\alpha_{\mathrm{IIb}} \beta_{3}$, functional analysis of fibrinogen-binding capacity is essential. Therefore, specific monoclonal antibodies against fibrinogen (FITC fibrinogen) or activated $\alpha_{\mathrm{IIb}} \beta_{3}$ (PAC-1) have to be applied $[10,11]$. The detection of trace amounts of intracellular $\alpha_{\text {IIb }}$ or $\beta_{3}$ in a patient's platelets by western blotting can give clues to the identity of the affected gene, while the presence of non-processed precursor pro- $\alpha_{\text {IIb }}$ will suggest a block in the integrin biosynthesis [8]. GT is classified into 3 subtypes, depending on the level of present $\alpha_{\text {II }} \beta_{3}$. Patients with type I or classical GT are homozygous or compound heterozygous for the disease and have a virtual absence of $\alpha_{\text {IIb }} \beta_{3}(<5 \%$ of normal). Type II GT patients can have up to $25 \%$ of the normal level of complex. In the variant type, $\alpha_{\text {II }} \beta_{3}$ levels are near normal but functionally impaired, leading to defective binding of fibrinogen [12]. Heterozygotes for type I GT have approximately $50 \%$ of the normal level of platelet $\alpha_{\mathrm{IIb}} \beta_{3}$, without bleeding problems. Using labor-intensive and time-consuming molecular genetic methods, a variety of mutations within the two genes for $\alpha_{\text {IIb }}$ (ITGA2B) and $\beta_{3}$ (ITG3B) have been identified (database: sinaicentral.mssm.edu/intranet/research/ glanzmann). Hemorrhagic symptoms, such as mucocutaneous bleeding with epistaxis and purpura, gingival bleeding and menorrhagia, occur only in patients homozygous or compound heterozygous for GT. Heterozygous phenotypes with $50-70 \%$ functional $\alpha_{\mathrm{IIb}} \beta_{3}$ show no significant reduction in platelet aggregation and are mostly asymptomatic [12]. The extent of bleeding depends on the amount of $\alpha_{\mathrm{II}} \beta_{3} ; 20-30 \%$ functional $\alpha_{\text {IIb }} \beta_{3}$ seems to be sufficient to prevent severe bleeding [13]. 


\section{Bernard-Soulier Syndrome}

The Bernard-Soulier syndrome (BSS) is a rare autosomal recessive disease associated with bleeding tendency, giant platelets, and thrombocytopenia [14, 15]. Electron microscopy often shows many cytoplasmic vacuoles and zones enriched in membrane complexes in the giant platelets, abnormalities that extend to megakaryocytes (MKs). Based on data from Europe, North America and Japan, the prevalence of homozygous BSS has been estimated at less than 1 in 1,000,000 [16] but is probably higher due to misdiagnosis and underreporting. According to the Hardy-Weinberg law, the frequency of the heterozygous phenotype is 1 in 500. The thrombocytopathy is due to quantitative and/or qualitative defects of the GPIb-IX-V complex. The glycoprotein (GP) Ib-IX-V complex on platelets initiates adhesion to vascular subendothelium at high shear stress by binding the adhesive ligand von Willebrand Factor (vWF). Patients with classical BSS are homozygous or compound heterozygous for mutations in the GPI $\alpha$, GPIb $\beta$, or GPIX genes [17-28]. Most of the mutations identified are point mutations that produce premature stop signals and unstable peptides. Missense mutations that affect functional domains are also widespread. In homozygous BSS bleeding, symptoms usually manifest rapidly after birth or during early childhood. Clinical manifestations usually include purpura, epistaxis, gingival bleeding and menorrhagia, and more rarely gastrointestinal bleeding and hematuria. Severe bleeding episodes are associated with surgery, dental extraction, menses, delivery, or accidents. However, the severity and frequency of bleeding symptoms vary between individuals, even within a single family. Heterozygous carriers are mostly asymptomatic but in some cases a mild to moderate bleeding tendency has been reported [29]. The initial laboratory assessment of BSS should involve measurement of blood cell counts and examination of a blood smears because a constant feature of BSS is the presence of a small number of very large platelets with a rounded shape (main volume $11-16 \mu \mathrm{m}^{3}$; diameter 4-10 $\mu \mathrm{m}$ ) [30]. In homozygous patients, the platelet count ranges from 10,000 to $280,000 / \mu 1$, and in heterozygous patients from very low $(20,000 / \mu \mathrm{l})$ to normal values, indicating that thrombocytopenia is a variable feature of this condition [18]. Manual counting is necessary for precise quantification because the very large platelets in BSS are often mistaken for lymphocytes in automatic cell counters. The distinctive abnormality in BSS is an isolated defect in ristocetin-induced agglutination. Platelet aggregation independent of the GPIb-IX-V/ vWF interaction, such as that induced by collagen, adenosine diphosphate (ADP) or epinephrine, is usually within the normal range, however decreased responses to thrombin can be observed. The provisional diagnosis based on aggregometry should be confirmed by flow cytometry by using a panel of monoclonal antibodies (CD42a-d). Finally, molecular studies of genetic abnormalities allow precise definition of the platelet defect.

\section{Platelet-Type or Pseudo-von Willebrand Disease}

Platelet-type von Willebrand disease (PTvWD) is a rare autosomal dominant bleeding disorder caused by the increased affinity of the GPIb $\alpha$ receptor toward its ligand, vWF [31]. This promotes clearance of the larger vWF multimers from the blood and initiates a more rapid platelet turnover, causing mild macrothrombocytopenia. These clinical and laboratory features resemble those in patients with type $2 \mathrm{~B} v \mathrm{vD}$ except that the disorder is caused by an abnormal receptor rather than abnormal ligand [32]. Patients have decreased factor VIII-ristocetin cofactor activity and enhanced platelet agglutination at low concentrations of ristocetin $(\leq 0.5 \mathrm{mg} / \mathrm{ml})$.

\section{Deficient Collagen Receptor Functions}

Deficient collagen receptor function has been described in several unrelated patients with mucocutaneous bleeding symptoms. GPIa-IIa $\left(\alpha_{2} \beta_{1}\right)$ is a mediator of platelet adhesion to fibrillar collagens at sites of vascular injury. Platelets from a patient described by Nieuwenhuis et al. [33, 34] had a GPIaIIa deficiency (15-25\% of normal platelet GPIa) and failed to aggregate in response to collagen, or adhere and spread normally to subendothelial surfaces. Kehrel et al. [35] reported a patient with markedly reduced collagen-induced aggregation, and a deficiency in GPIa and thrombospondin. Selective impairment in collagen responses and a mild bleeding disorder have also been related to GPVI deficiency [36-38]. In a family with gray platelet syndrome and defective collagen adhesion, it was shown that the cause of abnormal platelet-collagen interaction is due to GPVI deficiency [39]. GPIV (CD36) has also been implicated in the collagen response. Platelet adhesion to collagen is reduced in the absence of functional GPIV, and this reduction occurs at the earliest stages of the adhesion process [40]. However, a single defect in GPIV may not result in clinical bleeding but may become symptomatic in combination with other defects such as autoantibodies against GPIa/ IIa, GPIV, and/or GPIIb/IIIa [41]. 3-11\% of the Japanese and approximately $0.3 \%$ of the US population have a lack of GPIV receptor and are asymptomatic $[42,43]$.

\section{Enzyme Deficiencies}

Some thrombocytopathies are caused by congenital deficiencies of cyclooxygenase-1, prostaglandin $\mathrm{H}$ synthetase-1, thromboxane synthetase, lipoxygenase, glycogen-6 synthetase, and enzymes of the adenosine triphosphate (ATP) metabolism.

\section{Deficiency of Granule Stores: Storage Pool Disease (SPD)}

This heterogeneous group of inherited disorders is characterized by variable reduction in the number and content of granules in megakaryocytes and platelets. The disorder is associated with mild or severe bleeding symptoms. It may present as an isolated platelet function defect, or be associ- 
ated with a variety of congenital or acquired disorders. Platelets contain 4 main types of cytoplasmic granules classified according to their respective ultrastructures, densities, and content: the $\alpha$-granules, the $\delta$-granules (or $\delta$-bodies), the lysosomes, and the peroxisomes. SPD platelets require the use of electron microscopy for reaching a definitive diagnosis.

$\delta$-SPD patients lack $\delta$-granules resulting in a deficiency of ADP, ATP, and serotonin, which when released, enhance platelet aggregation. Platelet aggregation studies typically show a significantly impaired second wave of aggregation when stimulated by ADP, epinephrine, or thrombin. The most consistent finding is that adenine nucleotides are reduced with an increased ratio of ATP to ADP and normal levels of lysosomal enzymes [44]. When platelet deficiencies of $\delta$-granules are associated with abnormalities of other lysosome-related organelles, they cause clearly defined phenotypes. The best known are Hermansky-Pudlak syndrome (HPS), Griscelli syndromes, and Chediak-Higashi syndrome (CHS) where melanosomal defects result in a pattern of hypopigmentation [45].

More rarely, patients have $\alpha$-SPD or the gray-platelet syndrome (GPS). In this defect, platelets appear gray on WrightGiemsa-stained blood smears. Measurement of platelet ADP and ATP content and release are useful in the diagnosis of storage pool and release defects [46]. Most patients with GPS have a prolonged bleeding time and a bleeding diathesis that ranges from mild to severe, although life-threatening spontaneous hemorrhage is rare. Easy bruising, petechiae, mucosal membrane bleeding, and postsurgical or traumatic bleeding may occur. The Quebec platelet disorder (QPD) is an autosomal dominant bleeding disorder characterized by mildly reduced normal platelet counts, an epinephrine aggregation defect, multimerin deficiency, and proteolytic degradation of several soluble $\alpha$ granular proteins $[47,48]$. The fact that bleeding responds to fibrinolytic inhibitors rather than platelet transfusions led to the discovery that platelets in this disorder possessed unusually large amounts of urokinase-type plasminogen activator, a protein that is released on platelet activation $[4,49]$. Combined $\alpha \delta$ granule deficiencies are less common than the isolated defects. In these defects, patients have marked deficiencies of $\delta$-granules combined with variable reduction in platelet $\alpha$-granules. Clinically, these patients behave much like $\alpha$ - or $\delta$-SPD patients and respond to the same treatments.

\section{Macrothrombocytopenias (Giant Platelet Syndromes)}

Inherited macrothrombocytopenias comprise a group of heterogeneous diseases characterized by a reduction in the number but an increase in the volume of platelets with varying degrees of platelet dysfunction $[50,51]$. The 4 most common defects - May-Heggelin anomaly, Fechtner syndrome, Sebastian syndrome, and Epstein syndrome - belong to the group of MYH9-related diseases affecting the non-muscle myosin heavy-chain IIA (myosin-IIA). Several of the giant platelet syndromes have associated membrane protein de- fects. For example patients with BSS as previously described have also giant platelets and mild thrombocytopenia. Since electronic counters measure platelets by enumerate platelets within a specified volume window (e.g. 2-20 fl), they fail to recognize the oversized platelets and therefore platelet count is underestimated. To overcome this problem in platelet counting, an immunological method using flow cytometry has been developed. This method, as ratified by the International Society of Laboratory Hematology (ISLH), is now the proposed international reference method (IRM) for counting platelets [52].

\section{Diagnostics and Differential Diagnosis}

\section{Suspicion of Bleeding Disorder - Diagnostic Strategy (Step 1)}

Currently, there are no guidelines regarding the diagnosis or treatment of patients with platelet function disorders. However, in daily practice physicians are frequently confronted with patients suffering from excessive bleedings or sometimes bleeding for no apparent reason. This comprises profuse and/ or prolonged nose and gum bleeding, petechia, menorrhagia, or prolonged bleeding after cuts, abrasions, or injuries. Periand postoperative bleeding is also a frequently observed complication in the hospital setting. In these situations different questions must be asked: i) Is it a pathological bleeding or is the bleeding within the upper norm range? Mild bleeding disorders remain a challenge to diagnose because discrimination between normality and a pathological bleeding tendency is difficult. ii) Is the bleeding due to a congenital/familial or acquired disorder? iii) Which part of blood coagulation is affected - primary hemostasis (platelet or blood vessel wall problems) or secondary hemostasis (coagulation problems)? iv) Does the patient have a systemic disease that could cause or exacerbate the bleeding? v) Does the patient take any medication that may cause or exacerbate the bleeding tendency?

When the bleeding history and/or family history are suspicious, it is common practice to proceed to a staged series of investigations to confirm an abnormality of primary hemostasis or coagulation and to determine a precise diagnosis [53, 54]. Although in most cases a detailed anamnesis may be sufficient to distinguish between a platelet abnormality and coagulation abnormality (petechiae, mucocutaneous bleeding, delayed secondary bleeding, wound healing disorder), there is a general consensus that a few first stage tests: platelet counts, prothrombin time (PT), and activated partial thromboplastin time (aPTT) are carried out (table 2). To exclude congenital or acquired defects of plasmatic coagulation factors that influence primary hemostasis, in the first instance the vWF (because of vWD) and the fibrinogen level (because of hypo- or afibrinogenemia) have to be investigated (for further parameters see table 1). Thrombin time is not systematically performed but is considered as a screening test. The blood count 
Table 2. Diagnostic approach to laboratory investigation (stage 1)

\begin{tabular}{|c|c|c|}
\hline Test & Assessment & Material \\
\hline $\begin{array}{l}\text { Blood count incl. platelet count and mean } \\
\text { platelet volume (MPV), blood smear }\end{array}$ & $\begin{array}{l}\text { Detection/exclusion of thrombocytopenia, indication } \\
\text { of giant platelet disorders }\end{array}$ & $\begin{array}{l}\text { EDTA-anticoagulated whole blood; } \\
\text { citrate-anticoagulated whole blood in } \\
\text { the case of EDTA-dependent } \\
\text { pseudothrombocytopenia }\end{array}$ \\
\hline $\begin{array}{l}\text { Coagulation tests: } \\
\text { PT, aPTT, TT, FXIII, reptilase time, } \\
\text { fibrinogen concentration, vWF antigen, } \\
\text { ristocetin- cofactor, collagen binding } \\
\text { assay }\end{array}$ & $\begin{array}{l}\text { Detection/exclusion of coagulation disorder. In case } \\
\text { of prolonged PT/aPTT relevant factor assays should } \\
\text { be performed, with inhibitor assay if indicated. } \\
\text { A lupus inhibitor test should be performed in the } \\
\text { view of isolated prolongation of the aPTT }\end{array}$ & $\begin{array}{l}\text { plasma from citrated whole blood } \\
\text { (citrated blood) }\end{array}$ \\
\hline
\end{tabular}

\begin{tabular}{ll}
\hline Standardized skin bleeding time & Prolonged bleeding time may be caused by drugs Mielke method, Duke method \\
& (e.g. acetylsalicylic acid) or is due to platelet \\
& function disorders
\end{tabular}

Platelet function analyzer (PFA-100) closure time is influenced by pre-analytical variables citrated blood
(platelet number, hematocrit, acetylsalicylic acid, and particularly vWF). Sensitivity is variable in congenital platelet disorders. The values are significantly prolonged in GT and BSS patients (closure time $>300$ s with collagen/ADP and epinephrine/collagen cartridges). In SPD, HPS and QPS patients, PFA may be sensitive but false-negative results can often occur

Platelet aggregation using the Born method
or impedance aggregometry with:
ADP, collagen, arachidonic acid,
epinephrine, ristocetin in concentration
series and limiting concentrations
Several thrombocytopathies have typical aggregation patterns (table 3). Also platelet inhibitors (e.g. acetylsalicylic acid, clopidogrel, or GP IIb/IIIa receptor antagonists) or other drugs such as high-dose ibuprofen and some antibiotics inhibit certain agonist-induced aggregations

aPTT = Activated partial thromboplastin time; BSS = Bernard-Soulier syndrome; GT = Glanzmann thrombasthenia;

HPS = Hermansky-Pudlak syndrome; PT = prothrombin time; QPS = Quebec platelet syndrome; SPD = storage-pool-disease;

$\mathrm{TT}=$ thrombin time; $\mathrm{vWF}=$ von Willebrand factor.

provides information about platelet number and volume distribution. Skin bleeding time is a poorly reproducible test that does not predict bleeding risk. It is only diagnostically conclusive if conducted by a highly motivated and experienced operator who knows of the many variables influencing bleeding time. The template bleeding time is the most frequent and best-standardized method. The in vitro bleeding time using the platelet function analyzer (PFA) is also increasingly used in the first stage assays [55]. The PFA-100 ${ }^{\circledR}$ system (Siemens Healthcare Diagnostics, Deerfield, IL, USA) mimics an artificial vessel and consists of a capillary and a biologically active membrane with a central aperture coated with two agonists (either collagen plus ADP or collagen plus epinephrine). The PFA-100 device simulates primary hemostasis at high shear and is therefore particularly sensitive to decreased vWF levels but also to some platelet disorders. In the platelet function disorders, its use as a screening test is a matter of more controversy, particularly because PFA-100 is poorly sensitive to platelet secretion defects which represent the most common abnormalities of platelet function. Light transmission ag- gregometry (LTA) is the gold standard for assessment of platelet function disorders. There are congenital platelet disorders exhibiting a characteristic aggregation pattern, e.g. primary aggregation abnormalities as in GT or secondary aggregation defects due to a low content of dense bodies, as observed in SPD. Platelet aggregation with at least ADP, collagen, arachidonic acid, and ristocetin should be used in the first step of screening (table 3 ). When a pathological value is measured in some of the screening tests, further investigations (stage 2) are necessary because different platelet functions (e.g. primary activation, adhesion and aggregation capability, platelet secretion, and procoagulant activity of platelets) may be affected in thrombocytopathy.

\section{Further Analysis for Diagnostic Assessment (Stage 2)}

In the case of pathological results for bleeding time, PFA-100, platelet aggregation, and/or a still unexplained bleeding tendency with the tests performed so far, further laboratory in- 
Table 3. Differential aggregation responses in patients with thrombocytopathies

\begin{tabular}{|c|c|c|c|c|}
\hline Syndrome & $\mathrm{ADP}$ & Collagen & $\begin{array}{l}\text { Arachidonic } \\
\text { acid }\end{array}$ & Ristocetin \\
\hline Glanzmann thrombasthenia & $\boldsymbol{\nabla}-\varnothing$ & $\nabla-\varnothing$ & $\nabla-\varnothing$ & $\mathrm{n}-\boldsymbol{\nabla}$ \\
\hline Bernard-Soulier syndrome & $\mathrm{n}$ & $\mathrm{n}$ & $\mathrm{n}$ & $\nabla-\varnothing$ \\
\hline May-Hegglin syndrome & $\mathrm{n}-(\boldsymbol{\nabla})$ & $\mathrm{n}$ & $?$ & $\mathrm{n}$ \\
\hline$\delta$-Storage pool disease & $\mathrm{n}-\boldsymbol{\nabla}$ & $\boldsymbol{\nabla}$ & $\mathrm{n}-\boldsymbol{\nabla}$ & $\mathrm{n}-\boldsymbol{\nabla}$ \\
\hline$\alpha$-Storage pool disease & $\mathrm{n}-\boldsymbol{\nabla}$ & $\nabla$ & $\mathrm{n}$ & $\mathrm{n}$ \\
\hline Aspirin-like defect & $\nabla$ & $\boldsymbol{\nabla}$ & $\nabla$ & $\mathrm{n}$ \\
\hline
\end{tabular}

vestigation is required (stage 2). Many of these tests can be very expensive, time-consuming, and need to be carried out in specialized hemostaseologic laboratories. However, it is not recommended to use shipped blood samples for analysis of platelet function because the measurements are dependent on the age of the blood samples. Therefore, patients often have to be examined on-site in hemostaseologic laboratories. Also in these cases, the physician should keep in mind that the results are influenced by preanalytical variables such as difficult venepuncture, undisclosed drug contamination (acetylsalicylic acid, heparin), and excessive citrate concentrations due to erythrocytosis. A further important point is that for most laboratory tests normal values are established using the mean value and 2 standard deviations from a representative population. Consequently, $2.5 \%$ of normal subjects will have a slightly prolonged clotting time.

Flow cytometric methods with specific monoclonal antibodies are used for qualitative and quantitative analysis of important surface receptors, e.g. GPIIb/IIIa, GPIb/IX/V, GPIa/ IIa, and GPIIIb. For example, the function of GPIIb/IIIa is analyzed after ADP or TRAP (thrombin receptor activating protein) stimulation using fluorescein-isothiocyanate-(FITC)labeled anti-fibrinogen antibody or PAC-1 (procaptase activating compound 1) directed against activated GPIIb/IIIa. With the help of flow cytometric analysis, some activation and secretion defects can be detected by preparing concentration series of activators and measuring the granule receptors (secretion marker) CD62 ( $\alpha$-granule) and CD63 ( $\delta$-granule). Flow cytometry is also capable of detecting signal transduction defects in platelets. For this purpose, phosphorylationspecific antibodies have been developed that measure the phosphorylation state of specific intracellular platelet proteins, e. g. VASP (vasodilator-stimulated phosphoprotein) or MAP kinase (mitogen-activated protein). In addition, with flow cytometric analysis of mepacrine-labeled platelets the (reduced) content of $\delta$-granules in anucleate platelets can be demonstrated as mepacrine binds particularly to adenine nucleotides. After a further activation step, the (impaired) secretion of $\delta$-granules can also be assessed.

The (reduced) content and (impaired) secretion of $\alpha$ - and $\delta$-granules may also be detected on the basis of release products (e.g. platelet factor 4, PDGF, ATP/ADP, or serotonin) by ELISA or luminometry (firefly method). The content of $\delta$-granules may also be evaluated by electron microscopy. For this, a drop of platelet-rich plasma (PRP) is placed on a coated grid, washed with distilled water, dried with wedges of filter paper, and then inserted into the electron microscope. $\delta$-granules appear as dark spots and can be counted.

Adhesion and spreading disorders are investigated by adhesion and spreading tests. Platelet adhesion to different surfaces such as collagen, fibrinogen, siliconized glass, and subendothelial matrix is evaluated. Platelet spreading is analyzed by light microscopy by measuring platelet size and volume. This method is also capable of detecting giant platelets. The special tests of stage 2 are summarized in table 4 .

In addition to the above mentioned tests, a lot of other tests can be done. For example, over the past years the thrombin generation test has emerged as a universal method for measuring hemostatic disorders. Evidence is growing that the parameters of the thrombogram, and notably the area under the curve (endogenous thrombin potential, ETP), are useful in assessing risk of both bleeding and thrombosis [56]. However, this assay has no proven place as a screening test for bleeding disorders in general so far, but we think that this test could be particularly useful in understanding why with the same hemostatic abnormality some subjects bleed whereas others do not bleed.

\section{Prophylaxis and Treatment of Bleeding in Patients with Platelet Disorders}

Patients with congenital and acquired thrombocytopathies/penies may require transfusion of blood products (e.g. platelet concentrates, PC) in the course of their life. Due to the infection risk, patients should be vaccinated against hepatitis A and B. Moreover, in thrombocytopathies/-penies with severe bleeding tendency the human leukocyte antigen (HLA) type should be determined so that patients can receive HLAmatched transfusions with minimized immunization risk. Patients should carry an emergency health card with information about the disease, therapy, contraindications (antiplatelet drugs), as well as the telephone number of the attending physician. 
Table 4. Further analysis (stage 2) for diagnostic assessment of thrombocytopathies/-penias (depending on the results of the first stage investigations)

\begin{tabular}{|c|c|c|}
\hline Test & Assessment/detection & Material \\
\hline $\begin{array}{l}\text { Repetition of platelet aggregation from stage } 1 \\
\quad \text { (see table 1) }\end{array}$ & $\begin{array}{l}\text { verification of results; if results are suggestive, } \\
\text { perform platelet granule secretion assay }\end{array}$ & PRP from citrated blood \\
\hline \multicolumn{3}{|l|}{ Flow cytometry } \\
\hline $\begin{array}{l}\text { Platelet receptors: e.g. GP-IIb/IIIa, } \\
\text { GP-Ib/XI/V }\end{array}$ & $\begin{array}{l}\text { reduced/absent GP-IIb/IIIa receptor (Glanzmann } \\
\text { thrombasthenia) or GP-Ib/IX/V receptor } \\
\text { (Bernard-Soulier syndrome) }\end{array}$ & \multirow{5}{*}{$\begin{array}{l}\text { PRP from citrated blood; } \\
\text { determination of receptor } \\
\text { count is possible in } 1 \text { - to } \\
\text { 2-days-old blood samples given } \\
\text { that a healthy controls sample } \\
\text { was also sent to the laboratory; } \\
\text { functional measurements } \\
\text { should be performed within } \\
3 \mathrm{~h} \text { after PRP preparation }\end{array}$} \\
\hline $\begin{array}{l}\text { Functional PAC-1 or fibrinogen binding to } \\
\text { GP-IIb/IIIa }\end{array}$ & reduced fibrinogen binding of GP-IIb/IIIa & \\
\hline $\begin{array}{l}\text { Activation marker: } \\
\text { CD62 (receptor of } \alpha \text {-granules) } \\
\text { CD63 (receptor of } \delta \text {-granules) }\end{array}$ & activation- and/or secretion-deficiency & \\
\hline Mepacrine staining & reduced/absent $\delta$-granules & \\
\hline $\begin{array}{l}\text { Signal transduction: } \\
\text { VASP } \\
\text { MAP kinase }\end{array}$ & phosphorylation defects & \\
\hline
\end{tabular}

Other procedures

Platelet adhesion (microscopically)

adhesion to different surfaces (siliconized glass, collagen, fibrinogen, subendothelial matrix); defects in Glanzmann thrombasthenia,

Bernard-Soulier syndrome, different giant platelets thrombocytopathies

Platelet spreading (microscopically)

Volume distribution (microscopically, cell counter), blood smear

Plasma exchange test, MAIPA (monoclonal antibody immobilization of platelet antigens test)

Platelet granule-secretion assay, luminometry (firefly method), ELISA (serotonin detection)

ELISA (PF4, PDGF, $\beta$-thromboglobulin)

Electron microscopy of platelets

\section{size of platelets}

giant platelets (Bernard-Soulier syndrome, May-Hegglin anomaly), leukocytes inclusions (May-Hegglin anomaly and related diseases)

detection of platelet antibodies in acquired autoantibody induced

thrombocytopenia/thrombocytopathy

ATP content and ATP secretion, serotonin-content ( $\delta$-storage pool disease)

PF4-, PDGF-, $\beta$-thromboglobulin-content $(\alpha$-storage pool disease)

$\alpha$ - or $\delta$-storage pool defect; particularly

$\delta$-granules are presentable with easy

preparation technique
PRP from citrated blood

PRP from citrated blood PRP from citrated blood, EDTA-anticoagulated whole blood

PRP from citrated blood

PRP from citrated blood

PRP from citrated blood

\section{Local Measures}

Local bleeding, such as nose or gum bleeding, in patients with platelets disorders may usually be stopped with conservative local measures including nose pads and/or fibrin sealants which contain fibrinogen, thrombin, factor XIII and aprotinin, or fibrin-coated collagen fleece. Proper oral hygiene is important to prevent gum bleeding. In the case of gum bleeding, mouth rinse with tranexamic acid can be helpful.

\section{Systemic Antifibrinolytic Therapy}

Antifibrinolytic agents, such as tranexamic acid, are effective in the management of bleeding in patients with thrombocytopathy/-penia. For the treatment of mucocutaneous bleed- ing, menorrhagia, or gastrointestinal bleeding tranexamic acid is given orally (usually $2-3$ times $1,000-1,500 \mathrm{mg}$ daily) or intravenously as monotherapy or additional therapy. However, an important disadvantage of tranexamic acid is its low bioavailability of about $30 \%$, necessitating frequent intake of high doses.

\section{Desmopressin}

The vasopressin analog desmopressin (1-desamino-8-Darginine vasopressin; Minirin ${ }^{\circledR}$, Ferring, Saint-Prex, Switzerland) shortens the bleeding time in storage pool deficiencies. Desmopressin can be administered parenterally either via intravenous or subcutaneous injection or intranasally as drops or spray. The recommended parenteral dose is $0.3 \mu \mathrm{g} / \mathrm{kg}$ body 
weight, and the intranasal dose is $300 \mu \mathrm{g}$. Desmopressin stimulates the release of endothelial vWF and enhances platelet adhesion to the vessel wall. The effectiveness of desmopressin for prevention and treatment of bleeding was also shown in other thrombocytopathies. However, response to desmopressin is highly variable among patients with different platelet disorders and may not be sufficient. In patients with receptor defects, e.g. GT, therapy with desmopressin is not effective. In patients with thrombocytopenia, desmopressin does not shorten the bleeding time. Side effects of desmopressin include flushing, changes in blood pressure, hypersensitivity reactions (rash, fever, bronchospasm), fluid retention, and/or hyponatremia. Fluid intake should be adjusted to reduce the possibility of water intoxication and hyponatremia especially in very young and elderly patients. Particular attention should be paid to the risk of an extreme decrease in plasma osmolality and resulting seizures in young children. However, seizures may also occur without fluid retention. The antidiuretic effect of desmopressin is increased by clofibrate, indomethacin, carbamazepine, chlorpropamide, and tricyclic antidepressants.

\section{Platelet Concentrates}

A general indication for the transfusion of PCs is thrombocytopenic bleeding due to a platelet production defect or consumption/dilutional coagulopathy. In addition, severe bleeding complications or non-response to desmopressin after surgery or trauma justify the administration of PCs. Prophylactic administration of PCs in idiopathic thrombocytopenic purpura (ITP) is not recommended. Specific indications for platelet transfusions are: i) bleeding complications in inherited platelet disorders (e.g. GT, BSS); ii) emergency therapy of thrombocytopenic/-pathic bleeding in patients with disorders of megakaryopoiesis or increased platelet turnover (e.g. ITP, liver disease, or DIC); iii) thrombocytopenia after massive transfusion; iv) prophylaxis in thrombocytopenia/-pathy and bleeding risk as well as preoperative [57]. The PC dosage is dependent on the patient's clinical condition, the extent of the thrombocytopenia, the target value of the platelet number, and factors that influence platelet survival time and platelet function. One unit of platelets $\left(2-4 \times 10^{11}\right.$ platelets $)$ would be expected to increase the platelet count of an adult patient (70 kg) by 20,000-30,000/ $\mu$ l. Young children and newborns should receive $10 \mathrm{ml} \mathrm{PC} / \mathrm{kg}$ body weight. The efficacy of platelet transfusion is assessed on the basis of the clinical effect (hemostasis), the increase in the number of platelets, and possibly on the basis of platelet function (e.g. bleeding time). Immunological or non-immunological refractoriness may be the cause of an insufficient increment in the platelet count after transfusion. Immunological refractoriness is primarily caused by HLA antibody-mediated destruction of transfused platelets, although HPA and high-titer ABO alloantibodies have occasionally been implicated. In such a case not only
ABO- but also HLA-compatible platelets should be given. Patients with GT have a particularly high risk for alloimmunization. Prevention is best accomplished by using leukocytedepleted blood products. Use of platelets matched via HLA is a further attempt to prevent platelet alloimmunization.

\section{Recombinant Activated Factor VIIa (rFVIIa)}

rFVIIa (NovoSeven ${ }^{\circledR}$, Novo Nordisk Inc., Bagsvaerd, Denmark) is often used in thrombocytopathic/-penic patients suffering from bleeding that can not be stopped by conventional treatments. Best reported data concerning the efficacy of rFVIIa is documented in thrombasthenic patients. Poon et al. [58] analyzed the data of an international registry for the treatment and prophylaxis of patients with GT and found that prophylaxis with rFVIIa in 29 out of 31 thrombasthenic patients undergoing surgery was effective. On the basis of this study, European approval for rFVIIa was obtained for thrombasthenic patients with antibodies against GPIIb/IIIa and/or HLA and with refractoriness to platelet transfusion therapy. Patients with GT receive at least 3 bolus injections at doses of $80-120 \mu \mathrm{g} / \mathrm{kg}$ body weight every $1.5-3 \mathrm{~h}$ until hemostasis [59]. Recently, a single dose of $270 \mu \mathrm{g} / \mathrm{kg}$ was approved in Europe on the basis of a study comparing $90 \mu \mathrm{g} / \mathrm{kg}$ three times per bleed with one single bolus of $270 \mu \mathrm{g} / \mathrm{kg}$. In the meantime, the above-mentioned dosage (at least 3 bolus doses of $80-120 \mu \mathrm{g} /$ $\mathrm{kg}$ rFVIIa) is also used for the treatment of severe bleeding complications in patients with BSS, storage pool diseases, and several acquired thrombocytopathies. In approximately half of the patients with thrombocytopenias, a single bolus of rFVIIa has been shown to be sufficient in managing otherwise untreatable bleeding complications. In these patients, hemostasis was achieved even at platelet counts $<20,000 / \mu$ l, although the efficacy of rFVIIa increases at higher platelet counts [60, 61]. Case reports reveal that the use of rFVIIa is more effective when administered early in a bleeding episode than it is when administered late. In 28 acute bleeding episodes in 7 children with platelet disorders (5 GT, 1 BSS, 1 SPD) $73 \%$ of the bleedings could be stopped when rFVIIa was administered $<12 \mathrm{~h}$ from onset of bleeding. Presentation $>12 \mathrm{~h}$ from onset of bleeding was an unfavorable feature; only $25 \%$ had an excellent or good response $[61,62]$. Whether further bolus injections of rFVIIa are necessary after successful hemostasis has to be decided empirically in each case [61]. Today, the therapeutic application of rFVIIa in patients with thrombocytopenia of different origin is largely empirical. There are only a few casuistics with rFVIIa alone or in combination with PCs available reporting about successful treatment. The use of rFVIIa in thrombocytopenia should be limited to life-threatening or conservative non-treatable bleeding complications. However, to increase the effect of rFVIIa, a prompt transfusion of PC should be considered taking into account the riskbenefit ratio $[60,61]$. 


\section{Bone Marrow Transplantation}

Since 1985, only a few patients with severe GT, WiskottAldrich syndrome, or CHS have undergone bone marrow transplantation resulting in normalization of platelet function and megakaryopoiesis.

\section{Conclusion}

The inherited platelet function defects are a heterogeneous collection of rare bleeding disorders with symptoms that range in severity from mild to life-threatening. The precise diagnosis of a platelet function defect remains a challenge, even for specialists. Despite advances in the understanding of the etiology of these defects, in the vast majority of patients with inherited platelet disorders, the underlying mechanisms remain unknown. The treatment of platelet function disorders will depend on the particular type of disorder as well as the severity of the bleeding. Transfusion of platelets remains the primary therapy of severe bleeding. Alternatively, rFVIIa (90-120 $\mu \mathrm{g} / \mathrm{kg}$ bolus infusion) can be given. In contrast to receptor defects (GT), platelet function defects (storage pool diseases $)$ can be treated with desmopressin $(0.3 \mu \mathrm{g} / \mathrm{kg}$ body weight intravenously, or in the case of mild bleeding with Octostim $^{\circledR}$ spray (Ferring)) and/or cyclokapron (tranexamic acid $20 \mathrm{mg}$ orally).

\section{Disclosure}

The authors declared no conflict of interest.

\section{References}

1 Koscielny J, Ziemer S, Radtke H, Schmutzler M, Kiesewetter H, Salama A, von Tempelhoff GF: Preoperative identification of patients with impaired (primary) haemostasis. A practical concept. Hämostaseologie 2007;27:177-84.

2 Scharf RE: Acquired platelet function disorders: pathogenesis, classification, frequency, diagnosis, clinical management. Hämostaseologie 2008;28: 299-311.

$\checkmark 3$ Scharf RE: Congenital and acquired platelet function disorders. Hämostaseologie 2003;23:170-80.

$\checkmark 4$ Nurden P, Nurden AT: Congenital disorders associated with platelet dysfunctions. Thromb Haemost 2008;99:253-63.

5 Nurden At, Nurden P: Inherited disorders of platelets: an update. Curr Opin Hematol 2006;13:157-62.

6 Rao AK: Inherited defects in platelet signaling mechanisms J Thromb Haemost 2003;1:671-81.

7 Rao AK: Congenital disorders of platelet function: disorders of signal transduction and secretion. Am J Med Sci 1998;69-76.

8 Nurden AT: Glanzmann thrombasthenia. Orphanet J Rare Dis 2006;1:10.

-9 Caen JP: Glanzmann's thrombasthenia. Clin Haematol 1989;2:609-25.

10 Wilcox DA, Wautier JL, Pidard D, Newman PJ: A single amino acid substitution flanking the fourth calcium binding domain of alpha IIb prevents maturation of the alpha IIb beta 3 integrin complex. J Biol Chem 1994;269:4450-7.

11 Ruiz C, Liu CY, Sun QH, Sigaud-Fiks M, Fressinaud E, Muller JY, Nurden P, Nurden AT, Newman PJ, Valentin N: A point mutation in the cysteinerich domain of glycoprotein (GP) IIIa results in the expression of a GPIIb-IIIa (alphaIIbbeta3) integrin receptor locked in a high-affinity state and a Glanzmann thrombasthenia-like phenotype. Blood 2001;98:2432-41.

12 George JN, Caen JP, Nurden AT: Glanzmann's thrombasthenia: the spectrum of clinical disease. Blood 1990;75:1383-95.

13 Kirchmaier CM, Schirmer A, Jablonka B, Meyer M, Just M, Breddin HK: Correlation of bleeding complications in patients with the number of platelet GPIIb-IIIa receptor in patients with thrombasthenia Glanzmann. Ann Haemat 1992;64:abstr 19.
14 Nurden AT, George JN: Inherited abnormalities of the platelet menbrane: Glanzmann thrombasthenia, Bernard-Soulier syndrome, and other disorders; in Hemostasis and Thrombosis, 5th ed. Philadelphia, Lippincott, Williams and Wilkins, 2006, pp. 987-1010.

15 De Marco L, Mazzucato M, Fabris F, De Roia D, Coser P, Girolami A, Vicente V, Ruggeri ZM: Variant Bernard-Soulier syndrome type bolzano. A congenital bleeding disorder due to a structural and functional abnormality of the platelet glycoprotein Ib-IX complex. J Clin Invest 1990;86:25-31.

16 Kostopanagiotou G, Smyrniotis V, Arkadopoulos N, Contis J, Briassoulis G, Kostopanagiotou E: Anaesthetic and perioperative management of paediatric organ recipients in nontransplant surgery. Paediatr Anaesth 2003;13:754-63.

17 Nurden AT, Caen JP: Specific roles for platelet surface glycoproteins in platelet function. Nature 1975;255:720-2.

18 Lopez JA, Andrews RK, Afshar-Kharghan V, Berndt MC: Bernard-Soulier syndrome. Blood 1998;91:4397-418.

19 Noris P, Arbustini E, Spedini P, Belletti S, Balduini CL: A new variant of Bernard-Soulier syndrome characterized by dysfunctional glycoprotein (GP) $\mathrm{Ib}$ and severely reduced amounts of GPIX and GPV. Br J Haematol 1998;103:1004-13.

20 Kunishima S, Tomiyama Y, Honda S, Kurata Y, Kamiya T, Ozawa K, Saito H: Cys97 $\rightarrow$ Tyr mutation in the glycoprotein IX gene associated with Bernard Soulier syndrome. Br J Haematol 1999;107:539-45.

21 Hayashi T, Suzuki K, Akiba J, Yahagi A, Tajima $\mathrm{K}$, Satoh S, Sasaki H: G $\rightarrow$ A transition at nucleotide 2110 in the human platelet glycoprotein (GP) IX gene resulting in Ala139(ACC) $\rightarrow \operatorname{Thr}($ GCC) substitution. Jpn J Hum Genet 1997;42:369-71.

22 Iwanaga M, Kunishima S, Ikeda S, Tomonaga M, Naoe T: Vulnerable mutation Trp126 $\rightarrow$ stop of glycoprotein IX in Japanese Bernard-Soulier syndrome. Eur J Haematol 1998;60:264-6.

23 Kenny D, Jonsson OG, Morateck PA, Montgomery RR: Naturally occurring mutations in glycoprotein Ibo that result in defective ligand binding and synthesis of a truncated protein. Blood 1998; 92:175-83
24 Margaglione M, D'Andrea G, Grandone E, Brancaccio V, Amoriello A, Di Minno G: Compound heterozygosity (554-589 del, C515-T transition) in the platelet glycoprotein Ibalpha gene in a patient with a severe bleeding tendency. Thromb Haemost 1999;81:486-92.

25 Koskela S, Partanen J, Salmi TT, Kekomaki R: Molecular characterization of two mutations in platelet glycoprotein (GP) Ib alpha in two Finnish Bernard-Soulier syndrome families. Eur J Haematol 1999;62:160-8.

26 Koskela S, Javela K, Jouppila J, Juvonen E, Nyblom O, Partanen J, Kekomäki R: Variant BernardSoulier syndrome due to homozygous Asn45Ser mutation in the platelet glycoprotein (GP) IX in seven patients of five unrelated Finnish families. Eur J Haematol 1999;62:256-64.

27 Antonucci JV, Martin ES, Hulick PJ, Joseph A, Martin SE: Bernard-Soulier syndrome: common ancestry in two African American families with the GP Ib $\alpha$ Leu129Pro mutation. Am J Hematol 2000;65:141-8.

28 Moran N, Morateck PA, Deering A, Ryan M, Montgomery RR, Fitzgerald DJ, Kenny D: Surface expression of glycoprotein $\mathrm{Ib}$ alpha is dependent on glycoprotein $\mathrm{Ib} \beta$ : evidence from a novel mutation causing Bernard-Soulier syndrome. Blood 2000;96: 532-9.

29 Savoia A, Balduini CL, Savino M, Noris P, Del Vecchio M, Perrotta S, Belletti S, Poggi, Iolascon A: Autosomal dominant macrothrombocytopenia in Italy is most frequently a type of heterozygous Bernard-Soulier syndrome. Blood 2001;97:1330-5.

30 Lanza F: Bernard-Soulier syndrome (hemorrhagiparous thrombocytic dystrophy). Orphanet J Rare Dis 2006;1:46.

31 Weiss HJ, Meyer D, Rabinowitz R, Pietu G, Girma J-P, Vicic WJ, Rogers J: Pseudo-von Willebrand's disease: an intrinsic platelet defect with aggregation by unmodified human factor VIII/von Willebrand factor and enhanced adsorption of its high-molecular-weight multimers. N Engl J Med 1982;306:326.

32 Miller JL, Cunningham D, Lyle VA, Finch CN: Mutation in the gene encoding the alpha chain of platelet glycopro- tein Ib in platelet-type von Willebrand disease. Proc Natl Acad Sci U S A 1991;88: 4761-5. 
\$3 Nieuwenhuis HK, Akkerman JW, Houdijk WP, Sixma JJ: Human blood platelets showing no response to collagen fail to express surface glycoprotein Ia. Nature 1985;318:470-2.

\34 Nieuwenhuis HK, Sakariassen KS, Houdijk WP, Nievelstein PF, Sixma JJ: Deficiency of platelet membrane glycoprotein Ia associated with a decreased platelet adhesion to subendothelium: a defect in platelet spreading. Blood 1986:68:692-5.

-35 Kehrel B, Balleisen L, Kokott R, Mesters R, Stenzinger W, Clemetson KJ, van de Loo J: Deficiency of intact thrombospondin and membrane glycoprotein Ia in platelets with defective collagen-induced aggregation and spontaneous loss of disorder. Blood 1988;71:1074-8.

36 Moroi M, Jung SM, Okuma M, Shinmyozu K: A patient with platelets deficient in glycoprotein VI that lack both collagen-induced aggregation and adhesion. J Clin Invest 1989;84:1440-5.

37 Ryo R, Yoshida A, Sugano W, Yasunaga M, Nakayama K, Saigo K, Adachi M, Yamaguchi N, Okuma M: Deficiency of P62, a putative collagen receptor, in platelets from a patient with defective collagen-induced platelet aggregation. Am J Hematol 1992;39:25-31.

-38 Rao AK: Inherited defects in platelet signaling mechanisms. J Thromb Haemost 2003;1:671-81.

39 Nurden P, Jandrot-Perrus M, Combrié R, Winckler J, Arocas V, Lecut C, Pasquet JM, Kunicki TJ, Nurden AT: Severe deficiency of glycoprotein VI in a patient with gray platelet syndrome. Blood 2004;104:107-14.

40 Diaz-Ricart M, Tandon NN, Carretero M, Ordinas A, Bastida E, Jamieson GA: Platelets lacking functional CD36 (glycoprotein IV) show reduced adhesion to collagen in flowing whole blood. Blood 1993;82:491-6.

41 Beer JH, Rabaglio M, Berchtold P, von Felten A, Clemetson KJ, Tsakiris DA, Kehrel B, Brandenberger S: Autoantibodies against the platelet glycoproteins (GP) IIb/IIIa, Ia/IIa, and IV and partial deficiency in GPIV in a patient with a bleeding disorder and a defective platelet collagen interaction. Blood 1993;82:820-9.

42 Yamamoto N, Ikeda H, Tandon NN, Herman J, Tomiyama Y, Mitani T, Sekiguchi S, Lipsky R, Kralisz U, Jamieson GA: A platelet membrane glycoprotein (GP) deficiency in healthy blood donors: Naka- platelets lack detectable GPIV (CD36). Blood 1990;76:1698-703.
43 Shibata Y, Kim N, Morita S, Ishijima A, Okazaki S: Monoclonal antibody OKM5 and platelet alloantibody anti-Nak(a) have the same specificity. Proc Jpn Acad 1990;66:41.

44 Weiss HJ, Lages B, Hoffmann T, Turitto VT: Correction of the platelet adhesion defect in deltastorage pool deficiency at elevated hematocrit possible role of adenosine diphosphate. Blood 1996; 87:4214-22.

45 Huizing M, Anikster Y, Gahl WA: HermanskyPudlak syndrome and Chediak-Higashi syndrome: disorders of vesical formation and trafficking. Thromb Haemost 2001;86:233-45.

46 Summerfield GP, Keenan JP, Brodie NJ, Bellingham AJ: Bioluminescent assay of adenine nucleotides: rapid analysis of ATP and ADP in red cells and platelets using the LKB luminometer. Clin Lab Haematol 1981;3:257-71.

47 Hayward CP, Rivard GE, Kane WH, Drouin J, Zheng S, Moore JC, Kelton JG: An autosomal dominant, qualitative platelet disorder associated with multimerin deficiency, abnormalities in platelet factor $\mathrm{V}$, thrombospondin, von Willebrand factor, and fibrinogen and an epinephrine aggregation defect. Blood 1996;87:4967-78.

48 Hayward CP, Cramer EM, Kane WH, Zheng S, Bouchard M, Massé JM, Rivard GE: Studies of a second family with the Quebec platelet disorder: evidence that the degradation of the alpha-granule membrane and its soluble contents are not secondary to a defect in targeting proteins to alpha-granules. Blood 1997;89:1243-53.

49 Kahr WHA, Zheng S, Sheth PM, et al.: Platelets from patients with the Quebec platelet disorder contain and secrete abnormal amounts of urokinase-type plas- minogen activator. Blood 2001;98: 257-265.

50 White JG: Structural defects in inherited and giant platelet disorders. Adv Hum Genet 1990;19:133234.

51 Mhawech P, Saleem A: Inherited giant platelet disorders. Classification and literature review. Am J Clin Pathol 2000;113:176-190.

52 Harrison P, Ault KA, Chapman S, Charie L, Davis B, Fujimoto K, Houwen B, Kunicka J, Lacombe F, Machin S, Raynor R, van Hove L, Onno W, van Assendelft OW: An inter laboratory study of a candidate reference method for platelet counting. Am J Clin Pathol 2001;115,448-59.
Favaloro EJ: Clinical utility of the PFA-100. Semin Thromb Hemost 2008;34:709-33.

54 Crescente M, Di Castelnuovo A, Iacoviello L, Vermylen J, Cerletti C, de Gaetano G: Response variability to aspirin as assessed by the platelet function analyzer (PFA)-100. Thromb Haemost 2008;99: 14-26.

55 Jilma B: Platelet function analyzer (PFA-100): a tool to quantify congenital or acquired platelet dysfunction. J Lab Clin Med 2001;138:152-63.

56 Hemker HC, Al Dieri R, De Smedt E, Béguin S: Thrombin generation, a function test of the haemostatic-thrombotic system. Thromb Haemost 2006 96:553-61.

57 Greinacher A, Kiefel V, Klüter H, Kroll H, Pötzsch B, Riess H: Recommendations for platelet transfusion by the Joint Thrombocyte Working Party of DGTI, GTH, DGHO. Dtsch Med Wochenschr 2006;131:2675-9.

58 Poon MC, D’Oiron R, Von Depka M, Khair K, Négrier C, Karafoulidou A, Huth-Kuehne A, Morfini $\mathrm{M}$; International Data Collection on Recombinant Factor VIIa and Congenital Platelet Disorders Study Group: Prophylactic and therapeutic recombinant factor VIIa administration to patients with Glanzmann's thrombasthenia: results of an international survey. J Thromb Haemost 2004;2:1096-103.

59 NovoSeven ${ }^{\circledR}$ - recombinant factor VIIa Novo Nordisk's EU Package Insert.

60 Poon MC: The evidence for the use of recombinant human activated factor VII in the treatment of bleeding patients with quantitative and qualitative platelet disorders. Transfus Med Rev 2007;21: 223-36.

61 Zotz RB, Scharf RE: (Recombinant factor VIIa in patients with platelet function disorders or thrombocytopenia). Hämostaseologie 2007;27:251-62.

62 Almeida AM, Khair K, Hann I, Liesner R: The use of recombinant factor VIIa in children with inherited platelet function disorders. Br J Haematol 2003;121:477-81. 